\title{
Politejsav fóliák pneumatikus alakíthatósági vizsgálatának fejlesztése
}

\section{Development of Pneumatic Deformability Test of Polylactic Acid Films}

\author{
Gere Dániel, ${ }^{1,2}$ Pölöskei Kornél ${ }^{3}$ \\ ${ }^{1}$ Budapesti Müszaki és Gazdaságtudományi Egyetem, Gépészmérnöki Kar, Polimertechnika Tanszék. \\ Budapest, Magyarország, gered@pt.bme.hu \\ 2 IMSYS Mérnöki Szolgáltató Kft. Budapest, Magyarország \\ ${ }^{3}$ Budapesti Müszaki és Gazdaságtudományi Egyetem, Gépészmérnöki Kar, Polimertechnika Tanszék. \\ Budapest, Magyarország, poloskei@pt.bme.hu
}

\begin{abstract}
The aim of the present study is to develop a test method suitable for modelling thermoforming processes and which provides an index that accurately characterises the thermoformability of a film or sheet at a given temperature and pressure. For this purpose, the elevated temperature pneumatic deformability test was considered to be the most suitable. During the test, the film is blown until it tears, which takes only a few seconds. We recorded blowing during the test, and used the images to determine the ascent $(k)$ of the specimens and approach the estimated surface of the deformed specimens with a sphere.
\end{abstract}

Keywords: polylactic acid, thermoforming, pneumatic deformability test, Burgers model.

\section{Összefoglalás}

Jelen tanulmányban egy olyan mérési eljárás fejlesztését tűztük ki célul, amely alkalmas a melegalakítási folyamatok modellezésére, és egy olyan mutatószámot szolgáltat, amely kiválóan jellemzi egy fólia vagy lemez melegalakíthatóságát adott hőmérsékleten, adott nyomásviszonyok mellett. Erre a célra az emelt hőmérsékletű, pneumatikus vizsgálatot tartottuk a leginkább alkalmasnak. A vizsgálat a fólia szakadásig történő fújását jelenti, ami mindössze néhány másodpercig tart. A vizsgálatról készült képfelvétel-sorozatok elemzésével határoztuk meg az emelkedési magasságot (k), valamint az alakváltozott próbatesteket, egy gömbbel közelítve a becsült felszínt.

Kulcsszavak: politejsav, melegalakítás, pneumatikus alakíthatósági vizsgálat, Burgers-modell.

\section{Bevezetés}

A modern környezetvédelmi törekvések miatt egyre inkább teret hódítanak a természetes alapú polimerek. Ezek közül kiemelkedik a felhasznált mennyisége és mechanikai tulajdonságai révén a politejsav (PLA) [1-3].

A 21. században rendkívüli mértékben megnövekedő árumozgások magukkal vonták a csomagolóipar robbanásszerű fejlődését, ami miatt előtérbe kerültek a melegalakítási eljárások [4-7].
A legtöbb polimerfeldolgozási eljárás esetén rendelkezésre állnak olyan mutatószámok, amelyek alapján közvetlenül meghatározható egy alapanyag feldolgozhatósága. Ezzel szemben a vákuum- és préslégformázáshoz nem kapcsolódnak ilyen mutatók. Nincs olyan egyszerü jellemző, amely közvetlen információt szolgáltat egy fólia vagy lemez melegalakítási eljárásokkal történő feldolgozhatóságáról. Jelen tanulmány célja egy ilyen mutatószám pontos meghatározására alkalmas mérési eljárás fejlesztése. Korábban vol- 
tak már kísérletek a melegalakítás modellezésére emelt hőmérsékletű, golyós repesztéssel, amelyek ugyan pontos erőelmozdulás görbét adtak, de mégsem szolgáltak egyértelmű mutatószámmal. E vizsgálat dinamikai viszonyai is messze elmaradtak a melegalakítás gyakorlati sebességétől. Az emelt hőmérsékletü, pneumatikus anyagvizsgálat könnyen követhetővé teszi a nagyobb sebességű alakváltozásokat [5-7].

Ennek a módszernek a dinamikai viszonyai sokkal közelebb állnak a melegalakítás gyakorlatához. A tanulmány célja ezen módszer alkalmazhatóságának a feltárása.

\section{Felhasznált anyagok}

A vizsgált fóliát a Budapesti Műszaki és Gazdaságtudományi Egyetem Polimertechnika Tanszékén Labtech Engineering Co., Ltd. LCR 300 típusú berendezéssel gyártottuk le. Az alapanyag NatureWorks LLC Ingeo Biopolymer 2003D típusú PLA-granulátum volt. Az egycsigás extruder csigájának fordulatszáma 54 1/min volt. A zónahőmérsékletek az elsőtől a szerszám felé 165165-170-175-180 ${ }^{\circ} \mathrm{C}$ voltak. A széles résű szerszám hőmérséklete $180^{\circ} \mathrm{C}$ volt. Az elhúzási sebesség $1 \mathrm{~m} / \mathrm{min}$ volt. A temperáló henger sebessége $0,6 \mathrm{~m} / \mathrm{min}$ volt, hőmérséklete $60^{\circ} \mathrm{C}$. A gyártott fólia $500 \mu \mathrm{m}$ névleges vastagságú. Üvegesedési hőmérséklete $55^{\circ} \mathrm{C}$.

\section{Mérési módszer}

\subsection{Mérőberendezés}

A berendezés fő része az AlMgSi 6061-es ötvözetből készült szerszám (1. ábra). A szerszám két félből áll, amelyek közé helyezzük a vizsgálni kívánt lemezt, fóliát. Az alsó szerszámfél tartalmaz egy tömítéshornyot, ahova egy 0 gyűrü kerül, valamint egy, a sűrített levegő bevezetésére szolgáló furatot. A felső szerszámfél cserélhető. Egy kisebb és egy nagyobb nyílású, mérő szerszámféllel is használható. A kisebb szerszámfél nyílása 79,8 mm furatátmérőjű, a nagyobb szerszámfél pedig 112,8 mm átmérőjü nyílással van ellátva. A mérések során a 79,8 mm átmérőjü szerszámfelet (Dsz) használtuk. Ennek az oka, hogy a nagyobb átmérőjű szerszámfélből hajlamos kicsúszni a próbatest a vizsgálat során. A két szerszámfél egymáshoz 4 db M8×18-as furattal és 4 db M8-as csavarral kapcsolódik.

A berendezés a fali sűrítettlevegő-hálózatra csatlakozik, ami jelen esetben 9 bar nyomású hálózatot jelentett. A sürített levegő egy $8 \mathrm{~mm}$ külső átmérőjű, poliuretán (PU) anyagú pneumatikai

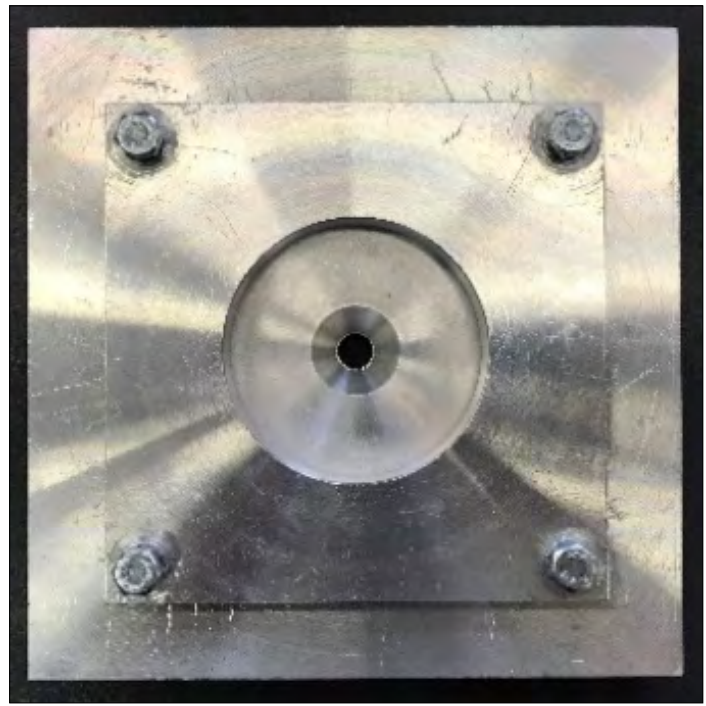

1. ábra. A pneumatikus alakíthatóságvizsgáló berendezés szerszáma

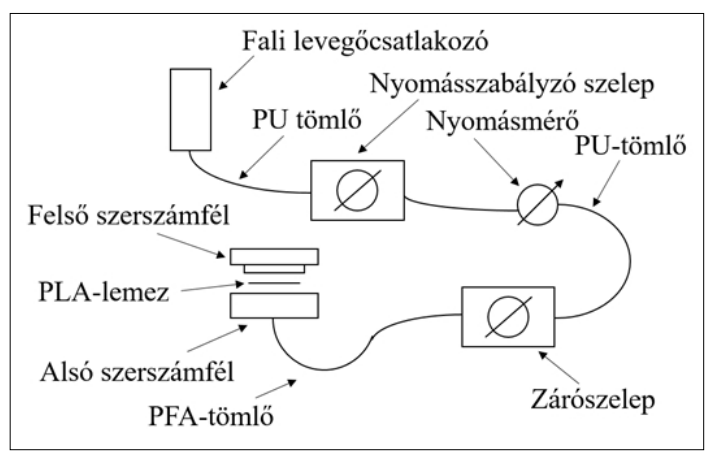

2. ábra. A mérőberendezés sematikus felépítése

csövön keresztül érkezik egy nyomásszabályozó szelepbe. A nyomásszabályozó szelep után egy nyomásmérő egység van beépítve, és ezután egy zárószelep. A zárószelep után a szerszámba egy $8 \mathrm{~mm}$ külső átmérőjü cső vezet, amely a szerszámhoz G 1/4"-es idommal csatlakozik. A berendezés sematikus felépítése a 2 . ábrán látható.

\subsection{A mérés menete}

A mérések elvégzéséhez a pneumatikus, alakíthatósági berendezést Zwick Z250 univerzális szakítógép hőkamrájába helyeztük meghatározott hőfokon 15 percre, majd a hőkamra ajtaját kinyitva, Nikon D3200 fényképezőgéppel filmfelvételt készítve, az adott nyomáson vizsgáltuk a fóliák viselkedését. E mérések során a fóliák tönkremeneteli magassága, tönkremenetelük módja és a kialakult „buborék” szimmetriája volt az elsődlegesen megállapítani kívánt jellemző. 
A mérés elrendezése a következő volt. A pneumatikus alakíthatósági berendezés a hőkamra alsó felén volt elhelyezve, így a szerszám felső lapja $800 \mathrm{~mm}$ magasságban volt. A fényképezőgép háromlábú állványon volt rögzítve. A fényképezőgép a szerszám felső lapjának síkja felett $50 \mathrm{~mm}$-rel magasabban, $850 \mathrm{~mm}$ magasságban volt elhelyezve, a szerszám középsíkjától 700 mm távolságban. A szerszám mögé 40 mm-re egy mérőskála került, amelynek nullpontja a fóliafúvó szerszámon belüli síkjával volt egy vonalban. A 3. ábra egy mérési folyamat egyik képkockáját mutatja. A videofelvételek másodpercenként 25 képkockát tartalmaznak. A fóliák tönkremenetelének megállapításához az első repedés megjelenése előtti képet vagy azt a képkockát vettük, ahol a tönkremenetelt okozó „kidudorodás” először megjelent.

Mivel a próbatest és a mérőskála két külön síkban helyezkedik el, ezért a képekről leolvasott értékeket korrigálni kell. A korrekciós értéket az (1) összefüggéssel számoltuk ki.

$$
\tan \beta=\frac{Y_{1}-50}{X_{1}}=\frac{Y^{*}}{X_{2}}
$$

Az (1) összefüggés átrendezésével kapjuk a (2) összefüggést.

$$
Y^{*}=\frac{X_{2} \cdot\left(Y_{1}-50\right)}{X_{1}}
$$

Jelen esetben $\mathrm{X}_{2}=140 \mathrm{~mm}$ és $\mathrm{X}_{1}=740 \mathrm{~mm}$. $\mathrm{Y}_{1}$ a leolvasott értéket jelöli, $\mathrm{Y}^{*}$ pedig a leolvasott magasság torzított részét. Így a kapott korrekciós öszszefüggés a (3) összefüggés:

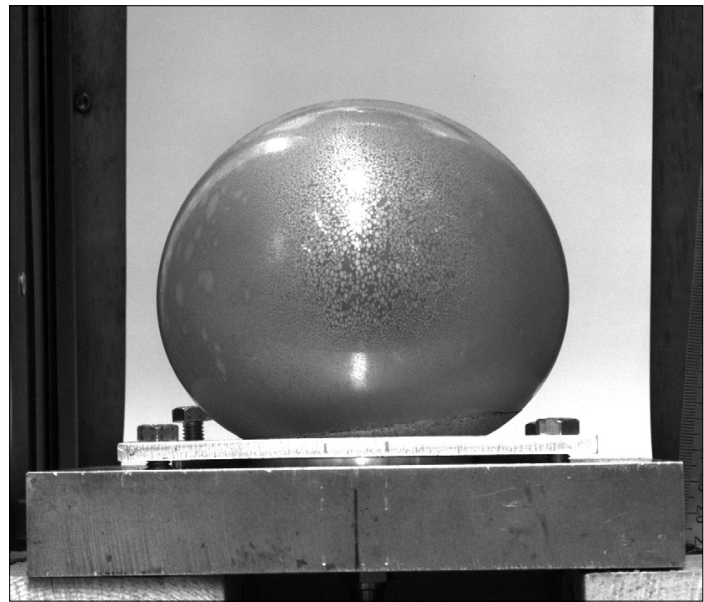

3. ábra. Egy mérési folyamat egyik képkockája a PLA 2003D fóliából fújt buborékról, a tönkremenetel előtt
$Y_{m}=Y_{1}-0,16667 \cdot\left(Y_{1}-50\right)$,

ahol $\mathrm{Y}_{\mathrm{m}}$ a „buborék” valós magassága. A torzításhoz használt geometriai modell a 4. ábrán látható.

A mérések során a minta a pneumatikus alakíthatósági berendezés alsó és felső szerszámfele közé volt rögzítve, majd a hőkamrában az adott hőmérsékleten 15 percet tartózkodott; ennyi idő alatt a próbadarab hőmérséklete megfelelően megközelíti a hőkamra hőmérsékletét.

\section{Mérési eredmények}

A próbatesteket $90{ }^{\circ} \mathrm{C}$-ra temperált hőkamrába helyeztük. Mérések előtt a célunk a fólia tönkremeneteli magasságának megállapítása volt. A mérések során azonban azt tapasztaltuk, hogy egy próbatest kivételével, 1 bar nyomás hatására a fólia nem szenvedett tönkremenetelt okozó alakváltozást. Az 1 bar nyomás hatására elszenvedett alakváltozás mértéke azonban így is hasznos információval szolgálhat. A kialakult buborékot körrel közelítettük, amelynek szimmetriáját a buborék középvonalával \pm 450 -ot bezáró két átmérő hányadosával jellemeztük. A szimmetria jellemzésére használt vonalak 450-os elhelyezése a középvonalhoz képest a szerszám okozta torzulást hivatott kiküszöbölni. Ez az arányszám 1 körüli érték esetén mutat nagyfokú szimmetriát. A méretek elhelyezkedését az 5 . ábra mutatja. A $d_{1}$ és $d_{2}$ meghatározásához a nyílt forráskódú GIMP képszerkesztő programot használtuk. A felvételek hátterében lévő méretskála segítségével két osztás közt található pixelek számát osztottuk

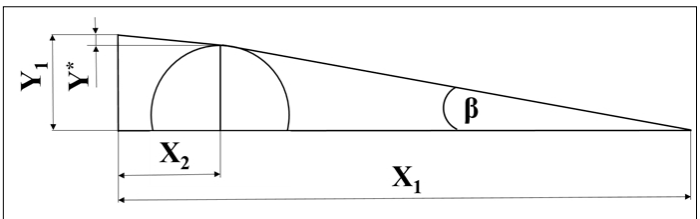

4. ábra. A geometriai modell

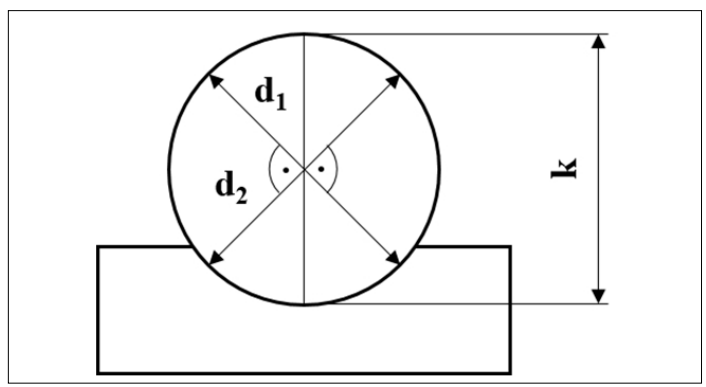

5. ábra. A méretek elhelyezkedése 
el a két osztás közti távolság korrigált értékével. Majd a szerszám középvonalán, a buborék felső vonalától lefele kijelöltük a $\mathrm{k}$ érték feléhez eső pontot. Abból a pontból kiindulva leolvastuk a $\mathrm{d}_{1}$ és $\mathrm{d}_{2}$ átmérők közti pixelek számát. A pixelek számát pedig megszoroztuk a méretskála osztásai közé eső pixelekre adódott távolságértékkel. Az 1. és 2. táblázat magasság oszlopában már a korrekció utáni érték szerepel.

$\mathrm{Az} 1$ bar-on végzett mérések eredményét az 1. táblázat tartalmazza.

Az adatokból látszik, hogy a fólia alakítási határa 15 perc, $90^{\circ} \mathrm{C}$-on való tartás után 1 bar hatására kicsivel $120 \mathrm{~mm}$ fölött van. A 2 bar-on végzett mérések eredménye a 2 . táblázatban található.

A két különböző nyomásértéken végzett mérések alapján az 500 ㅆm vastagságú 2003D PLA-fóliáról elmondható, hogy a mérés során kialakult buborék jó közelítéssel szimmetrikus.

Az alakításról készült videók esélyt adtak a fóliák megnyúlásának időbeli lefutásának vizsgálatára. A buborékképződés vizsgálatához a videó képsorozatából elemzett képek mintavételezési gyakoriságát annak függvényében választottuk meg, hogy milyen gyorsan zajlott le az alakítás. Az elemzett képek mintavételezési gyakoriságát úgy választottuk meg, hogy a kapott görbék jelle-

1. táblázat. A PLA 2003D fólia 1 bar-on végzett mérésének eredményei

\begin{tabular}{|c|c|c|c|}
\hline Minta & $\begin{array}{c}\text { Magasság, } \mathbf{k} \\
(\mathbf{m m})\end{array}$ & Tönkremenetel & $\mathbf{d}_{\mathbf{1}} / \mathbf{d}_{\mathbf{2}}$ \\
\hline 1. & 124,99 & igen & 0,994 \\
\hline 2. & 120,83 & nem & 1,010 \\
\hline 3. & 119,17 & nem & 0,996 \\
\hline 4. & 104,33 & nem & 1,047 \\
\hline 5. & 103,33 & nem & 1,004 \\
\hline
\end{tabular}

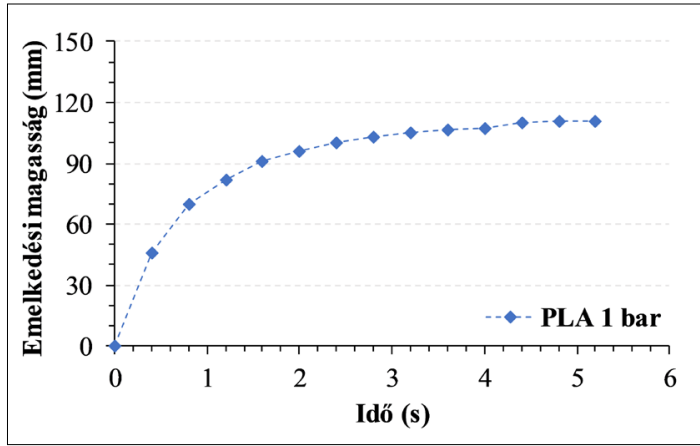

6. ábra. A PLA 2003D fólia 1 bar nyomással mért emelkedési magasság-idő diagramja ge megfeleljen a buborékképződés folyamatának. A PLA 2003D fólia 1 bar-os nyomással végzett alakításának vizsgálata során minden tizedik képkocka szolgált az alakváltozási méretek meghatározására. Ez 25 kép per másodperc esetén 0,4 másodpercenkénti mintavételt jelent. Az emelkedési magasság növekedésének időbeli változását az adatok kinyerése után emelkedési magasság-idő diagramban ábrázoltuk (6. ábra).

Az emelkedési magasság a kezdeti gyors növekedés után logaritmikus függvényalakot mutat, majd lassan beáll egy konstans értékre. Ebben az esetben a kísérlet nem járt a fólia tönkremenetelével.

A PLA 2003D fólia 2 bar-os mérésének kiértékeléséhez minden negyedik képkockát használtuk fel. Ez 0,16 másodpercenkénti mintavételt jelent. A gyakoribb mintavételt az indokolta, hogy a PLA 2003D anyagú fólia 2 bar nyomás hatására körülbelül $3 \mathrm{~s}$ alatt ment tönkre. A diagram a 7. ábrán látható.

A 2 bar-os görbét az 1 bar-os görbével összehasonlítva láthatjuk, hogy a 2 bar-os esetben az emelkedési magasság a kezdeti gyors alakváltozás után egy közel lineáris vonalat követ. Az 1 bar-on végzett mérésnél láthattuk, hogy az emelkedési magasság egy állandó értéken stabilizálódott, hiszen itt a mérés nem járt a buborék tönkremenetelével.

2. táblázat. A PLA 2003D fólia 2 bar-on végzett mérésének eredményei

\begin{tabular}{|c|c|c|c|}
\hline Minta & $\begin{array}{c}\text { Magasság, } \mathbf{k} \\
(\mathbf{m m})\end{array}$ & Tönkremenetel & $\mathbf{d}_{\mathbf{1}} / \mathbf{d}_{\mathbf{2}}$ \\
\hline 1. & 141,67 & igen & 1,013 \\
\hline 2. & 139,17 & igen & 1,010 \\
\hline 3. & 152,50 & igen & 0,979 \\
\hline 4. & 121,67 & nem & 0,968 \\
\hline 5. & 113,33 & nem & 1,025 \\
\hline
\end{tabular}

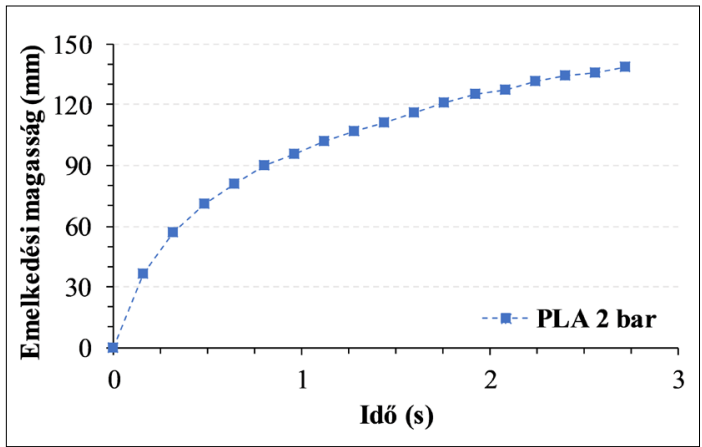

7. ábra. A PLA 2003D fólia 2 bar nyomással felvett emelkedési magasság-idő diagramja 
Az emelkedési magasság-idő diagramokból kísérletet tettünk egy, a fóliák alakváltozását leíró, a Burgers-modellel analóg modell paramétereinek megállapítására. A paraméterek megállapításához a diagram ordinátatengelyét át kell skálázni emelkedési magasságról felületmegnyúlás-értékekre. A fólia $\varepsilon$ felületi megnyúlását az alakított fólia $\mathrm{A}_{\mathrm{sz}}$ kezdeti területének (4) és az adott emelkedési magassághoz tartozó átmérőjű gömb $\mathrm{A}_{\mathrm{b}}$ felületének (5) hányadosaként definiáltuk (6).

A felületi megnyúlás számításánál fontos megjegyezni, hogy ennek a modellnek az alkalmazhatóságát jelentősen korlátozza az, hogy a buborék felszínét gömbként modellezi, ami a szerszám okozta torzítások miatt jelentős elhanyagolásokat tartalmaz. A préslevegős formázás kezdeti szakaszán a fólia felülete paraboloid alakú, ennek az állapotnak a leírására a gömb felületének képlete nagyságrendi hibát eredményez, ezért a formázás során a felületnyúlást csak 50 mm emelkedési magasság felett értelmeztük. A mérés során készített képek alapján ez az a minimális magasság, amely felett a gömbfelületet már megfelelően közelíti a kialakuló buborék. A fóliák megnyúlásának felületen történő kétirányú vizsgálatát az indokolta, hogy a melegalakítási eljárások esetében az alakítószerszám felülete egy mérhető és fontos jellemzője a szerszámnak.

$$
\begin{aligned}
& A_{s z}=\frac{D_{s z}^{2} \cdot \pi}{4} \\
& A_{b}=\frac{4 \cdot k^{2} \cdot \pi}{4} \\
& \varepsilon=\sqrt{\frac{A_{b}-A_{s z}}{A_{s z}}}
\end{aligned}
$$

A Burgers-modell paramétereinek kiszámolásához meg kell állapítanunk egy kezdeti feszültségértéket $\left(\sigma_{\mathrm{B}}\right)$ is. A feszültségérték megállapításához (9) a szerszámnyílás területén $\left(\mathrm{A}_{\mathrm{sz}}\right.$ ) ébredő $\mathrm{F}$ erőt (8) osztottuk el a fóliának az alakítása kezdetén nyírófeszültségnek kitett keresztmetszetével $\left(A_{f}\right)$. Ez az alakítószerszám kerületének $\left(\mathrm{D}_{\mathrm{sz}}\right)$ és a fólia vastagságának (v) a szorzatát jelenti (7).

$$
\begin{aligned}
& A_{f}=D_{s z} \cdot \pi \cdot v \\
& F=A_{s z} \cdot p \\
& \sigma_{B}=\frac{F}{A_{f}}
\end{aligned}
$$

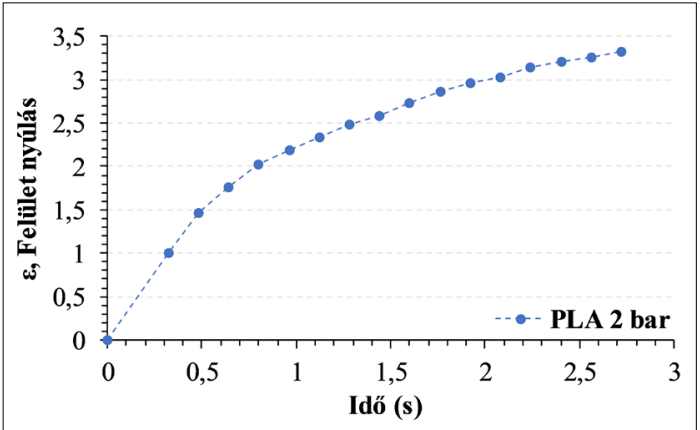

8. ábra. A PLA-fólia 2 bar-on végzett méréséből előállított felületi nyúlás-idő diagram

Az átskálázott felületi nyúlás görbéből és a kiszámított feszültségértékből megkezdhetjük a modellparaméterek számítását. A modell paramétereinek számítását a felületi nyúlás-idő diagramokból szerkesztettük ki.

Az egyik PLA 2003D próbatest 2 bar-os vizsgálatának felületi alakváltozásra átskálázott válaszgörbéjét a 8. ábrán láthatjuk.

A paraméterek meghatározásakor a pillanatnyi rugalmas alakváltozási komponenst elhanyagoltuk. Az anyag nagyrugalmas állapotában is képes pillanatnyi rugalmas alakváltozásra, ám ez az alakváltozás a többi komponens mellett elhanyagolható. Ebből következően az $\mathrm{E}_{1}$ paraméter kiesik.

A PLA 2003D fóliára 2 bar-os terhelésből számolt modellünk egyenlete (10):

$$
\varepsilon_{\ddot{o}}=\frac{\sigma_{B}}{12,997} \cdot t+\frac{\sigma_{B}}{4,836} \cdot\left(1-e^{-\frac{1,547 \cdot t}{4,836}}\right)
$$

A modellünk felállításának célja az volt, hogy a modell alapján más terhelésre $(\sigma)$ is kiszámíthatóvá váljon a várható felületi nyúlás $\left(\varepsilon_{\ddot{0}}\right)$ értéke az idő függvényében (t). A 2 bar-os próbatesttel meghatározott modell pontosságát egy 1 bar-os próbatest alakítási adatait felhasználva ellenőriztük. Az 1 bar-on tesztelt próbatest alakítása, t = 5,2 s-ig tartott. A fóliában 1 bar hatására ébredő feszültség, $\sigma_{\mathrm{B}}=3,98 \mathrm{MPa}$. Ezeket az értékeket a modellbe visszahelyettesítve, a modell alapján kiszámolt felületi megnyúlás értéke: $\varepsilon_{\ddot{o}}=2,27$. Ezzel szemben a fólia mért megnyúlása: $\varepsilon_{\mathrm{t}}=2,77$ volt.

\section{Következtetések}

A munkánk során sikerült bebizonyítanunk, hogy az emelt hőmérsékletű pneumatikus vizsgálat alkalmas a melegalakítási folyamatok modellezésére. Meghatároztunk egy egyszerű mutató- 
számot, az emelkedési magasságot (k), amelynek maximális értéke kiválóan jellemzi egy fólia vagy lemez melegalakíthatóságát adott hőmérsékleten, adott nyomáson. Ez az egyszerű mutatószám segít meghatározni a maximális alakváltozási képességet jó közelítéssel egyenletes biaxiális terhelés mellett. Eredményeinket validálja, hogy az emelkedési magasságból számolt megnyúlásokat az idő függvényében ábrázolhatjuk, és az így kapott görbére kiválóan illeszkedik a Burgers-modell. A kutatások folytatása során szükséges az egyes elhanyagolások hatásának feltárása, úgymint a gömbbel való geometriai közelítés, vagy a falvastagság-változás eloszlása az idő függvényében.

\section{Köszönetnyilvánítás}

A kutatást az „Értéknövelt, multifunkcionális biopolimer csomagolási rendszer kifejlesztése és gyártástechnológiájának megtervezése” című, NVKP_16-12016-0012 azonosító számú projekt támogatta. Gere Dániel köszönetét fejezi ki az Innovációs és Technológiai Minisztérium Kooperatív Doktori Programjának. A mérések elvégzésében nyújtott segítségéért köszönet illeti Dénes András alapszakos hallgatót.

\section{Szakirodalmi hivatkozások}

[1] Gere D., Czigany T.: Future trends of plastic bottle recycling: Compatibilization of PET and PLA. Polymer Testing, 81. (2020) 106160.

https://doi.org/10.1016/j.polymertesting.2019.106160
[2] Józó M., Cui L., Bocz K., Pukánszky B.: Processing induced segregation in PLA/TPS blends: Factors and consequences. eXPRESS Polymer Letters, 14/8. (2020) 768-779.

https://doi.org/10.3144/expresspolymlett.2020.63

[3] Singh S., Santana-Pérez O., Rodriguez C., Oksman K., Maspoch M. L.: Mechanical behaviour of poly(lactic acid)/cellulose nanocrystal nanocomposites: A comparative study between conventional tensile test and small punch test. eXPRESS Polymer Letters, 14/12. (2020) 1127-1136.

https://doi.org/10.3144/expresspolymlett.2020.92

[4] Hajba S., Tábi T.: Cross effect of natural rubber and annealing on the properties of poly(lactic acid). Periodica Polytechnica Mechanical Engineering, 63/4. (2019) 270-277.

https://doi.org/10.3311/PPme.12825

[5] Pölöskei K., Csézi G., Hajba S., Tábi T.: Investigation of the thermoformability of various D-Lactide content poly(lactic acid) films by ball burst test. Polymer Engineering and Science, 60. (2020) 1266-1277.

https://doi.org/10.1002/pen.25378

[6] Schwarzmann P., Illig: Thermoforming. 2. kiadás. Carl Hanser Verlag, München, 2019. 1-495.

[7] Ashter A.: Thermoforming of single and multilayer laminates. Plastic films technologies, testing, and applications. 1. kiadás. Elsevier, Oxford, 2014. 1-352. 